\title{
Photocleavage of DNA by copper(II) complexes
}

\author{
AKHIL R CHAKRAVARTY \\ Department of Inorganic and Physical Chemistry, Indian Institute of Science, Bangalore 560012 \\ e-mail: arc@ipc.iisc.ernet.in
}

\begin{abstract}
The chemistry of ternary and binary copper(II) complexes showing efficient visible lightinduced DNA cleavage activity is summarized in this article. The role of the metal in photo-induced DNA cleavage reactions is explored by designing complex molecules having a variety of ligands. Ternary copper(II) complexes with amino acid like L-methionone or L-lysine and phenanthroline base are efficient photocleavers of DNA. Complexes of formulation $\left[\mathrm{Cu}\left(\mathrm{L}^{\mathrm{n}}\right)(\mathrm{phen})\right]\left(\mathrm{ClO}_{4}\right)$ with NSO-donor Schiff base $\left(\mathrm{HL}^{\mathrm{n}}\right)$ and $\mathrm{NN}$-donor heterocyclic base 1,10-phenanthroline (phen) show significant cleavage of supercoiled (SC) DNA on exposure to red light at $\approx 700 \mathrm{~nm}$. The $d-d$ and CT electronic bands of the copper(II) complexes play important roles in DNA cleavage reactions. The mechanistic pathways are found to be dependent on the types of ligands present in the copper(II) complexes and the photo-excitation energy. While UV exposure generally proceeds via a type-II process forming singlet oxygen as the reactive species, red-light exposure leads to DNA cleavage following different mechanistic pathways, viz. type-I, type-II and photo-redox pathways. Ternary copper(II) complexes with phen as DNA binder and Schiff base with a thiomethyl group as photosensitizer, cleave SC DNA to its nicked circular (NC) form in a type-II process in red-light. The binary complex $\left[\mathrm{Cu}(\mathrm{dpq})_{2}\left(\mathrm{H}_{2} \mathrm{O}\right)\right]\left(\mathrm{ClO}_{4}\right)_{2}$ (dpq, dipyridoquinoxaline) cleaves DNA by photo-redox pathway at $694 \mathrm{~nm}$. The binuclear complex [Cu $\left.{ }_{2}(\mathrm{RSSR})_{2}\right]$, where $\mathrm{H}_{2} \mathrm{RSSR}$ is a Schiff base derived from 2-(thioethyl)salicylaldimine, cleaves SC DNA at $632.8 \mathrm{~nm}(\mathrm{CW} \mathrm{He}-\mathrm{Ne}$ laser) and $694 \mathrm{~nm}$ (ruby laser) involving sulphide (type-I process) and hydroxyl radicals (photo-redox pathway) as the reactive species.
\end{abstract}

Keywords. Copper(II) complexes; DNA photocleavage; red light laser; phenanthroline bases.

\section{Introduction}

Transition metal complexes that are suitable for binding and cleaving double-stranded DNA are of considerable current interest due to their various applications in nucleic acid chemistry like foot-printing and sequence-specific binding agents, for modelling the restriction enzymes in genomic research, and as structural probes for therapeutic applications in cancer treatment. ${ }^{1-10}$ Cleavage of DNA can be achieved by targeting its basic constituents like base and/or sugar by an oxidative pathway or by hydrolysis of phosphoester linkages. Iron and copper complexes are known to be useful for oxidative cleavage of DNA involving nucleobase oxidation and/or degradation of sugar by abstraction of deoxyribose hydrogen atom(s), while complexes containing strong Lewis acids like copper(II) and zinc(II) are suitable for hydrolytic cleavage of DNA. Oxidative cleavage of DNA could take place by chemical or photochemical means. Sigman and coworkers have reported bis(phen)copper(I) complex as the first copper-based "chemical nuclease" that cleaves DNA in the pres- ence of $\mathrm{H}_{2} \mathrm{O}_{2}$ and a thiol. ${ }^{1,11}$ Similarly, the anticancer antibiotic bleomycins containing iron cleave DNA in an oxidative manner. ${ }^{12,13}$

Complexes showing photo-induced cleavage of DNA have significant advantage over their "chemical nuclease" analogues in the absence of any other reagents like a reducing species and/or $\mathrm{H}_{2} \mathrm{O}_{2}$ for their activity. Besides, compounds cleaving DNA on photo-activation usually are known to show localized effects in therapeutic applications and are non-toxic in the absence of light. Such compounds are particularly useful in photodynamic therapy (PDT). ${ }^{14-16}$ The PDT drug Photofrin ${ }^{\circledR}$, which is a mixture of hematoporphyrin and its derivatives, is used for the treatment of lung and esophageal cancers. ${ }^{17}$ This drug, on photo-activation at $632 \mathrm{~nm}$, generates cytotoxic singlet oxygen in a type-II process. Binding of paramagnetic metal ion like copper(II) to porphyrin reduces the triplet state lifetime of porphyrin, thus making the complex ineffective for PDT applications. ${ }^{18,19}$ Non-porphyrinic organic compounds that are capable of cleaving DNA on exposure to red light are virtually unknown except phthalocyanine and re- 
lated dyes. In contrast, transition metal complexes having electronic bands in the visible region could be alternatives to porphyrins. There are only few reports on $3 d$ metal-based non-porphyrinic complexes cleaving DNA with low energy visible radiation prior to our work. ${ }^{20-22}$ We have made a systematic study using a variety of ternary and binary copper(II) complexes to explore their photo-induced DNA cleavage activity, primarily because of the presence of low energy $d-d$ bands in these complexes. Copper being a bio-essential element, its complexes showing flexibility in the coordination geometries are expected to find applications in nucleic acid chemistry as compared to the heavier $4 d$ and $5 d$ transition elements.

\section{Ternary copper(II) amino acid complexes ${ }^{23-25}$}

While amino acid and peptide-based metal complexes have been used extensively as synthetic hydrolases and chemical nucleases, there is virtually no report on their photonuclease activity. ${ }^{26-30}$ Amino acid and peptide conjugates having photoactive organic moieties are known to cleave SC DNA to its NC form on photo-irradiation at UV light. ${ }^{31-33}$ It has been observed that such organic molecules of the type "A-B", where amino acid (A) is linked to the photosensitizer (B), cleave DNA by a type-II process. These compounds are, however, inactive in the PDT window of 600-800 $\mathrm{nm}$. We have reported new ternary copper(II) complexes of the type " $\mathrm{A}-\mathrm{Cu}^{\mathrm{II}}$ B", where the amino acid (A), like L-methionine (Lmet) or L-lysine (L-lys), and the DNA binder (B) such as phenanthroline bases are covalently linked to the metal ion to explore the effect of the metal ion on the photo-induced DNA cleavage activity of the complexes (scheme 1). The complexes of formulation $[\mathrm{Cu}(\mathrm{L}-\mathrm{met}) \mathrm{B}(\mathrm{Solv})]\left(\mathrm{ClO}_{4}\right)(\mathbf{1 - 4})^{23,24}$ and $[\mathrm{Cu}(\mathrm{L}-$ lys) $\left.\mathrm{B}\left(\mathrm{ClO}_{4}\right)\right]\left(\mathrm{ClO}_{4}\right)(\mathbf{5}-\mathbf{8})^{25}$, where $\mathrm{B}$ is a heterocyc-

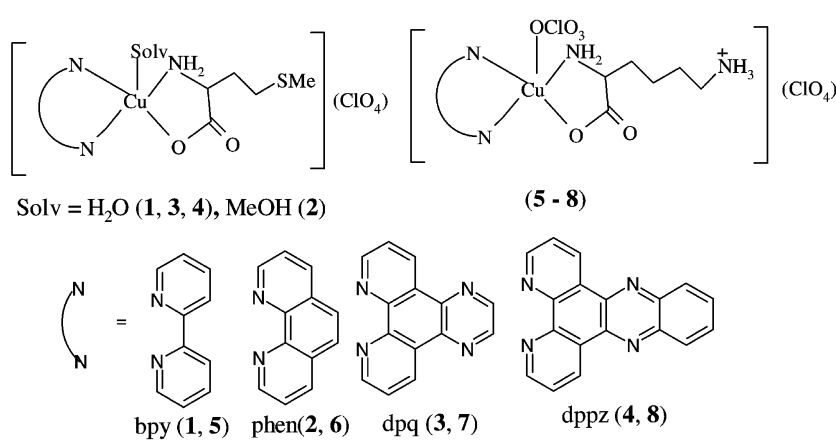

Scheme 1. Complexes 1-8 and the heterocyclic bases. lic base like 2,2'-bipyridine (bpy, 1, 5), 1,10-phenanthroline (phen, 2, 6), dipyrido[3,2-d:2', $3^{\prime}$-f] quinoxaline (dpq, 3, 7) and dipyrido[3,2-a:2',3'-c]phenazine (dppz, 4, 8), show efficient photo-induced DNA cleavage activity on irradiation with red light at $632.8 \mathrm{~nm}$ which is close to the photoactivation wavelength used for PDT drug Photofrin ${ }^{\circledR}$. Organometallic amino acid complexes are also known to photochemically cleave DNA on exposure to UV radiation. $^{34}$

Complexes other than the bpy species show binding to DNA at the minor groove for the phen and dpq species, while the dppz complexes bind at the major groove. The intrinsic binding constant $\left(K_{\mathrm{b}}\right)$ values for the complexes 2-4 and 6-8 vary in the range of $2 \cdot 0-8.0 \times 10^{3} \mathrm{M}^{-1}$ with the phenanthroline bases having extended aromatic rings showing higher binding propensity than phen. The photo-induced DNA cleavage activity of the L-met complexes is studied at $365 \mathrm{~nm}$ UV and $632.8 \mathrm{~nm} \mathrm{CW} \mathrm{He-Ne}$ laser ( $3 \mathrm{~mW}$ ) (figure 1, table 1). The bpy complex is cleavage inactive as this complex does not bind to DNA. The cleavage activity of the dpq and dppz complexes is significantly better than the phen complexes. The cleavage activity of the L-lysine complexes has been studied at $365 \mathrm{~nm}$ and $694 \mathrm{~nm}$ (pulsed ruby laser, $1 / 6 \mathrm{~Hz}, 20 \mathrm{~ns}$ ) (table 1 and figure 2). The complexes show efficient red light induced DNA cleavage activity with the L-lysine species being more active than the L-methionine analogues.

The photosensitizing effect of L-met and L-lys on copper-bound form is evidenced from the cleavage activity of their phen complexes as phen ligand itself is not a photosensitizer. It has been observed that

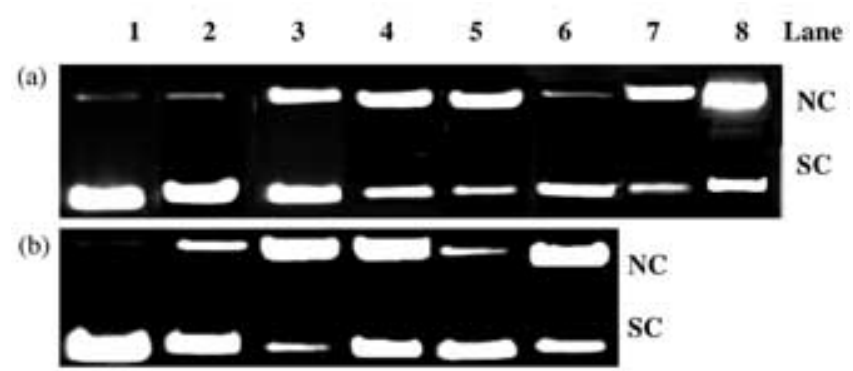

Figure 1. (a) Gel electrophoresis diagram showing UV light-induced DNA (SC pUC19, 0.5 $\mu \mathrm{g}$ ) cleavage activity of complexes 1-4 $(50 \mu \mathrm{M})$ at $365 \mathrm{~nm}(12 \mathrm{~W})$ with exposure time of $5 \mathrm{~min}$. (b) Gel diagram showing red lightinduced SC DNA $(0.5 \mu \mathrm{g})$ cleavage activity of complexes 2-4 $(100 \mu \mathrm{M})$ at $632.8 \mathrm{~nm}(\mathrm{CW} H \mathrm{He}-\mathrm{Ne}$ laser, $3 \mathrm{~mW})$ for an exposure time of $1.0 \mathrm{~h}$. Details of reaction conditions and $\%$ DNA cleavage data are given in table 1 . 
Table 1. Selected photo-induced DNA (SC pUC19, $0 \cdot 5 \mu \mathrm{g}$ ) cleavage data ${ }^{a}$ for the complexes [Cu(L-Met)B(Solv)] $\left(\mathrm{ClO}_{4}\right)(\mathbf{1}-\mathbf{4})$ and $\left[\mathrm{Cu}(\mathrm{L}-\mathrm{lys}) \mathrm{B}\left(\mathrm{ClO}_{4}\right)\right]\left(\mathrm{ClO}_{4}\right)(5-8)$.

Complex

\begin{tabular}{|c|c|c|c|c|c|c|c|c|}
\hline \multirow[b]{2}{*}{ S. no. } & \multicolumn{4}{|c|}{$[\mathrm{Cu}(\mathrm{L}-\mathrm{Met}) \mathrm{B}(\mathrm{Solv})]\left(\mathrm{ClO}_{4}\right)$} & \multicolumn{4}{|c|}{$\left[\mathrm{Cu}(\mathrm{L}-\mathrm{lys}) \mathrm{B}\left(\mathrm{ClO}_{4}\right)\right]\left(\mathrm{ClO}_{4}\right)$} \\
\hline & Reaction condition $^{\mathrm{b}}$ & $\lambda, \mathrm{nm}(t, \min )$ & $\mathrm{SC}(\%)$ & $\mathrm{NC}(\%)$ & Reaction condition & $\lambda, \mathrm{nm}(t, \min )$ & $\mathrm{SC}(\%)$ & $\mathrm{NC}(\%)$ \\
\hline (a) & & & & & (a) & & & \\
\hline 1 . & DNA control & $365[5]$ & 96 & 4 & DNA control & $365[60]$ & 97 & 3 \\
\hline 2. & DNA + 1 & $365[5]$ & 90 & 10 & $\mathrm{DNA}+\mathbf{5}^{\mathrm{c}}$ & $365[60]$ & 96 & 4 \\
\hline 3. & $\mathrm{DNA}+\mathbf{2}$ & $365[5]$ & 60 & 40 & $\mathrm{DNA}+\mathbf{6}^{\mathrm{d}}$ & $365[15]$ & 24 & 76 \\
\hline 4. & $\mathrm{DNA}+4$ & $365[5]$ & 40 & 60 & $\mathrm{DNA}+7^{\mathrm{c}}$ & $365[60]$ & 30 & 70 \\
\hline 5. & $\mathrm{DNA}+\mathbf{3}$ & $365[5]$ & 23 & 77 & $\mathrm{DNA}+\mathbf{8}^{\mathrm{c}}$ & $365[60]$ & 3 & 97 \\
\hline 6. & $\mathrm{DNA}+\mathrm{NaN}_{3}{ }^{\mathrm{e}}+\mathbf{3}$ & $365[5]$ & 87 & 13 & $\mathrm{DNA}+\mathrm{NaN}_{3}{ }^{\mathrm{f}}+\mathbf{6}^{\mathrm{d}}$ & $365[15]$ & 95 & 5 \\
\hline 7. & $\mathrm{DNA}+\mathrm{D}_{2} \mathrm{O}^{\mathrm{g}}+\mathbf{3}$ & $365[5]$ & 16 & 84 & $\mathrm{DNA}+\mathrm{D}_{2} \mathrm{O}^{\mathrm{g}}+\mathbf{6}^{\mathrm{d}}$ & $365[15]$ & 4 & 96 \\
\hline $\begin{array}{l}8 . \\
\text { (b) }\end{array}$ & $\mathrm{DNA}+\mathrm{DMSO}^{\mathrm{h}}+\mathbf{3}$ & $365[5]$ & 28 & 72 & $\begin{array}{l}\mathrm{DNA}+\mathrm{DMSO}^{\mathrm{h}}+\mathbf{6}^{\mathrm{d}} \\
\text { (b) }\end{array}$ & $365[15]$ & 38 & 62 \\
\hline 1 . & DNA control & $632 \cdot 8[60]$ & 95 & 5 & DNA control & $694[60]$ & 95 & 5 \\
\hline 2. & $\mathrm{DNA}+\mathbf{2}$ & $632 \cdot 8[60]$ & 68 & 32 & $\mathrm{DNA}+\mathbf{6}^{\mathrm{d}}$ & $694[60]$ & 38 & 62 \\
\hline 3. & $\mathrm{DNA}+\mathbf{3}$ & $632 \cdot 8[60]$ & 5 & 95 & $\mathrm{DNA}+7^{\mathrm{d}}$ & $694[60]$ & 7 & 93 \\
\hline 4. & $\mathrm{DNA}+4$ & $632 \cdot 8[60]$ & 32 & 68 & $\mathrm{DNA}+\mathbf{8}^{\mathrm{d}}$ & $694[60]$ & 8 & $92^{\mathrm{i}}$ \\
\hline 5. & $\mathrm{DNA}+\mathrm{NaN}_{3}{ }^{\mathrm{f}}+\mathbf{3}$ & $632 \cdot 8[60]$ & 81 & 19 & & & & \\
\hline 6. & $\mathrm{DNA}+\mathrm{DMSO}^{\mathrm{h}}+\mathbf{3}$ & $632 \cdot 8[60]$ & 20 & 80 & & & & \\
\hline
\end{tabular}

${ }^{\mathrm{a}}$ Serial numbers in this table correspond to the respective lane numbers given in figures $1 \mathrm{a}, \mathrm{b}$ and $2 \mathrm{a}$, b; ${ }^{\mathrm{b}} \mathrm{Complex}$ concentrations used are $50 \mu \mathrm{M}$ and $100 \mu \mathrm{M}$ at $365 \mathrm{~nm}$ and $632.8 \mathrm{~nm}$ respectively; ${ }^{\mathrm{c}} 25 \mu \mathrm{M} ;{ }^{\mathrm{d}} 50 \mu \mathrm{M} ;{ }^{\mathrm{e}} 90 \mu \mathrm{M}$; $100 \mu \mathrm{M}$; ${ }^{\mathrm{g}} 14 \mu \mathrm{l} ;{ }^{\mathrm{h}} 4 \mu \mathrm{l}$; ${ }^{\mathrm{i}}$ contains $8 \%$ linear form of DNA

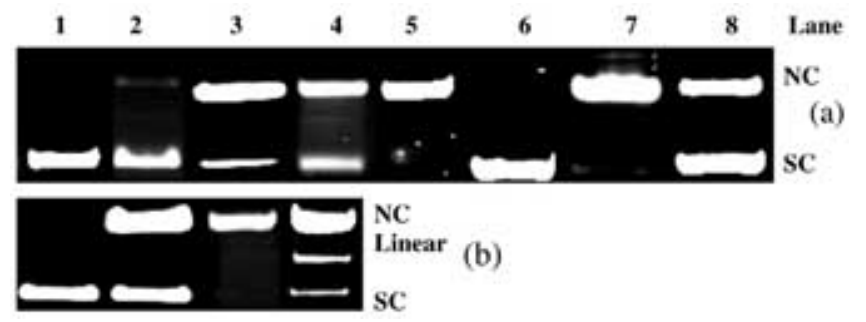

Figure 2. (a) Gel electrophoresis diagram showing UV light-induced SC DNA $(0.5 \mu \mathrm{g})$ cleavage activity of complexes 5-8 at $365 \mathrm{~nm}(12 \mathrm{~W})$. (b) Gel electrophoresis diagram displaying the red light-induced DNA (SC pUC $19,0.5 \mu \mathrm{g}$ ) cleavage activity of the complexes 6-8 $(50 \mu \mathrm{M})$ at $694 \mathrm{~nm}$ by pulsed ruby laser $(1 / 6 \mathrm{~Hz}, 20 \mathrm{~ns})$ with an exposure time of 60 min. Details of the reaction conditions and the \%DNA cleavage data are given in table 1 .

analogous L-phenylalanine complex $[\mathrm{Cu}(\mathrm{L}-\mathrm{phe})$ (phen) $\left.\left(\mathrm{H}_{2} \mathrm{O}\right)\right]^{2+}$ is cleavage-inactive at $\mathrm{UV}$ and visible wavelengths. It is interesting that while the amino acid and the phenanthroline base individually do not show any photo-induced DNA cleavage activity in red light, their ternary copper(II) complexes of the type "A-Cu" $\mathrm{C}$ " show efficient cleavage activity. The one-electron paramagnetic complexes display a $d-d$ band in the range $600-750 \mathrm{~nm}$. DNA cleavage activity in red light is believed to be metal-assisted in nature involving the metal centred electronic bands of lower molar absorbance in the photosensitization process. Control DNA cleavage experiments reveal the involvement of singlet oxygen as the cleavage active species. The complexes do not show any cleavage activity in the presence of singlet oxygen quencher sodium azide, but display significant enhancement of cleavage in $\mathrm{D}_{2} \mathrm{O}$ in which singlet oxygen has a longer lifetime. ${ }^{35}$ Addition of hydroxyl radical scavenger DMSO does not show any effect on the cleavage activity. Photoexcitation of the complexes seems to form an excited state followed by an efficient energy transfer to the triplet state which presumably activates oxygen from its stable triplet $\left({ }^{3} \Sigma_{g}^{-}\right)$to the highly toxic singlet $\left({ }^{1} \Delta_{g}\right)$ state. The significantly enhanced DNA cleavage activity of the L-lys complex over its L-met analogue could be due to the presence of the cationic amine moiety and better photosensitizing ability of the L-lys ligand. In the presence of bio-essential constituents like copper and amino acid, these complexes offer further scope of study for cellular applications in PDT. 


\section{Ternary copper(II) complexes with NSO-donor ligands ${ }^{36,37}$}

We have designed a new class of ternary copper(II) complexes $\left[\mathrm{Cu}\left(\mathrm{L}^{\mathrm{n}}\right)(\right.$ phen $\left.)\right]\left(\mathrm{ClO}_{4}\right)(\mathbf{9}, \mathbf{1 0})$, where $\mathrm{HL}^{\mathrm{n}}$ $(n=1,2)$ is tridentate NSO-donor Schiff base as a photosensitizer and phen as DNA binder. The objective of this work is to explore the role of the metal and the ancillary ligand having sulphur covalently linked to the metal to have enhanced photosensitizing ability of the complexes for red light-induced DNA cleavage activity (scheme 2). The rationale for choosing the NSO-donor Schiff base ligand is due to the fact that compounds containing thio or thione moieties generally have efficient intersystem crossing to the triplet state that eventually activates molecular oxygen from its stable triplet to the cytotoxic singlet state. ${ }^{38}$ For mechanistic investigations, a binary complex $\left[\mathrm{Cu}\left(\mathrm{L}^{2}\right)_{2}\right](\mathbf{1 1})$ and a ternary complex with ONO-donor Schiff base $\left[\mathrm{Cu}\left(\mathrm{L}^{3}\right)(\right.$ phen $\left.)\right]\left(\mathrm{ClO}_{4}\right)(\mathbf{1 2})$ are prepared and their photo-induced DNA cleavage property studied (scheme 2 ).

DNA binding studies show that the phen complexes bind DNA efficiently in the minor groove as evidenced from the control cleavage experiments using distamycin as the DNA minor groove binder. The binary species $\mathbf{1 1}$ does not show any apparent binding to DNA. The complexes are nuclease inactive in the dark in the absence of any external reagent. In the presence of a reducing agent like 3-mercaptopropionic acid, the phen complexes show chemical nuclease activity under dark reaction conditions.
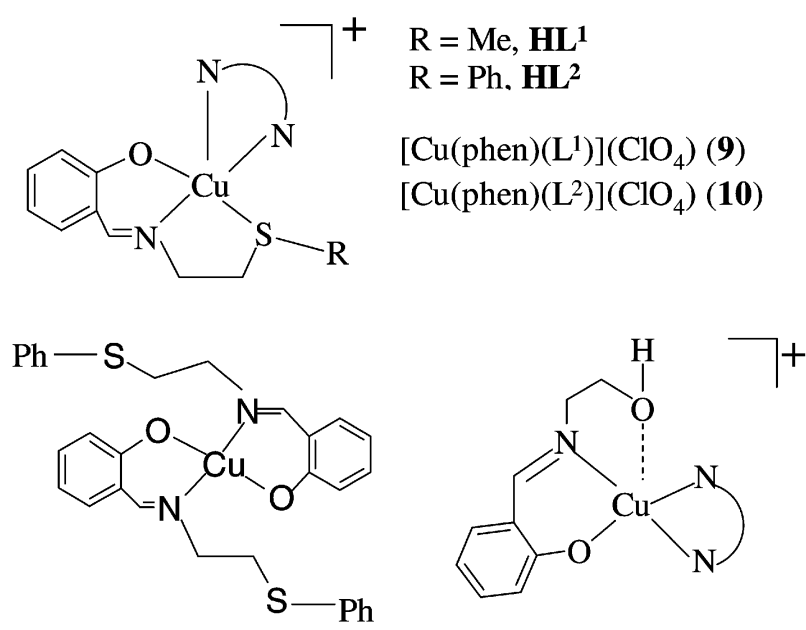

$\left[\mathrm{Cu}\left(\mathrm{L}^{2}\right)_{2}\right](\mathbf{1 1})$

$\left[\mathrm{Cu}(\right.$ phen $\left.)\left(\mathrm{L}^{3}\right)\right]\left(\mathrm{ClO}_{4}\right)$

(12)

Scheme 2. Structure of the copper(II) complexes 9-12.
The photonuclease activity of the complexes is initially studied using UV radiation of $312 \mathrm{~nm}(96 \mathrm{~W})$. The phen complexes with a $\mathrm{CuN}_{3} \mathrm{OS}$ core show significant cleavage of DNA from its SC to NC form (table 2, figure 3a). The results indicate the essential requirements of a photosensitizer (NSO-donor ligand) and a DNA binder (phen) in the complex for observing photo-induced DNA cleavage activity.

Visible light-induced DNA cleavage activity of two complexes having $\mathrm{CuN}_{3} \mathrm{OS}$ core has been studied at $532 \mathrm{~nm}$ (mercury vapor lamp, $125 \mathrm{~W}$ ) and $632.8 \mathrm{~nm}$ (CW laser, $3 \mathrm{~mW}$ ). Selected data are given in table 2 and figure $3 \mathrm{~b}$. The results show that the phen complex with a Schiff base with a thiomethyl group is more cleavage active than its analogue with a thiophenyl group. This could be due to the reduced triplet state lifetime of the thiophenyl moiety in the presence of an aromatic ring bound to the sulphur atom. The observed efficient DNA cleavage activity of complex 9 at $632.8 \mathrm{~nm}$ is significant as the porphyrin-based anticancer drug Photofrin ${ }^{\circledR}$ is active at this wavelength.

Mechanistic aspects of the DNA photocleavage reaction have been explored using visible radiation of different wavelengths (figure 4). The DNA minor group binder phen complex with a thiomethyl group does not show any apparent cleavage under argon atmosphere. The necessity of oxygen in the cleavage reactions is evidenced from the greater cleavage efficiency in pure oxygen than in air. Enhancement of DNA cleavage is also observed in $\mathrm{D}_{2} \mathrm{O}$, while addition of singlet oxygen quencher sodium azide inhibits the

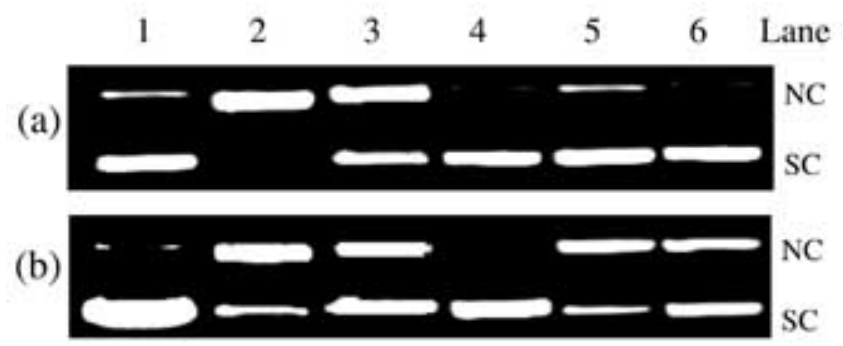

Figure 3. (a) Cleavage of SC pUC19 DNA $(0.5 \mu \mathrm{g})$ by the complexes 9-12 $(80 \mu \mathrm{M})$ under UV light (312 nm, 96 $\mathrm{W}$; 10 min exposure) followed by incubation under dark condition in $50 \mathrm{mM}$ Tris- $\mathrm{HCl} / \mathrm{NaCl}$ buffer $(\mathrm{pH}, 7 \cdot 2)$ containing DMF (10\%) and electrophoresis with particulars of the reaction conditions given in table 2. (b) Cleavage of SC pUC19 DNA by the phen complexes 9 and $\mathbf{1 0}$ using monochromatic radiation of $532 \mathrm{~nm}$ (mercury vapour lamp, $125 \mathrm{~W}$ ) (lanes 1-3) and $632.8 \mathrm{~nm} \mathrm{CW}$ laser (3 mW) (lanes 4-6) using different complex concentrations and exposure times with details of the reaction conditions given in table 2 . 
Table 2. Cleavage of SC pUC19 DNA $(0 \cdot 5 \mu \mathrm{g})^{\mathrm{a}}$ by 9-12 on irradiation with UV and visible light of different wavelengths and sources.

\begin{tabular}{|c|c|c|c|c|c|}
\hline S. no. & Reaction condition & Complex $(\mu \mathrm{M})$ & $\lambda, \operatorname{nm}(t, \min )$ & $\mathrm{SC}(\%)$ & $\mathrm{NC}(\%)$ \\
\hline & Light source: UV Light $(96 \mathrm{~W})$ (data for figure $3 \mathrm{a})$ & & & & \\
\hline 1. & DNA control & - & 312 [10] & 83 & 17 \\
\hline 2. & $\mathrm{DNA}+\left[\mathrm{Cu}\left(\mathrm{L}^{1}\right)(\right.$ phen $\left.)\right]\left(\mathrm{ClO}_{4}\right)(\mathbf{9})$ & 80 & $312[10]$ & 5 & 95 \\
\hline 3. & $\mathrm{DNA}+\left[\mathrm{Cu}\left(\mathrm{L}^{2}\right)(\right.$ phen $\left.)\right]\left(\mathrm{ClO}_{4}\right)(\mathbf{1 0})$ & 80 & $312[10]$ & 40 & 60 \\
\hline 4. & $\mathrm{DNA}+\left[\mathrm{Cu}\left(\mathrm{L}^{2}\right)_{2}\right](\mathbf{1 1})$ & 80 & $312[10]$ & 86 & 14 \\
\hline 5. & $\mathrm{DNA}+\left[\mathrm{Cu}\left(\mathrm{L}^{3}\right)(\right.$ phen $\left.)\right]\left(\mathrm{ClO}_{4}\right)(\mathbf{1 2})$ & 80 & $312[10]$ & 71 & 29 \\
\hline 6. & DNA + Schiff base $\left(\mathrm{HL}^{1}\right)$ & 80 & $312[10]$ & 92 & 8 \\
\hline \multicolumn{6}{|c|}{ Light source: Mercury vapour lamp (125 W) (data for figure 3b) } \\
\hline 1. & DNA control & - & $532[10]$ & 90 & 10 \\
\hline 2. & $\mathrm{DNA}+\left[\mathrm{Cu}\left(\mathrm{L}^{1}\right)(\right.$ phen $\left.)\right]\left(\mathrm{ClO}_{4}\right)(\mathbf{9})$ & 80 & $532[15]$ & 32 & 68 \\
\hline 3. & $\mathrm{DNA}+\left[\mathrm{Cu}\left(\mathrm{L}^{2}\right)(\right.$ phen $\left.)\right]\left(\mathrm{ClO}_{4}\right)(\mathbf{1 0})$ & 100 & $532[30]$ & 53 & 47 \\
\hline \multicolumn{6}{|c|}{ Light source: $\mathrm{CW} \mathrm{He}-\mathrm{Ne}$ laser (3 $\mathrm{mW}$ ) (data for figure $3 \mathrm{~b})$} \\
\hline 4. & DNA control & - & $632.8[15]$ & 96 & 4 \\
\hline 5. & $\mathrm{DNA}+\left[\mathrm{Cu}\left(\mathrm{L}^{1}\right)(\right.$ phen $\left.)\right]\left(\mathrm{ClO}_{4}\right)(\mathbf{9})$ & 150 & $632.8[15]$ & 38 & 62 \\
\hline 6. & $\mathrm{DNA}+\left[\mathrm{Cu}\left(\mathrm{L}^{2}\right)(\right.$ phen $\left.)\right]\left(\mathrm{ClO}_{4}\right)(\mathbf{1 0})$ & 200 & $632.8[15]$ & 50 & 50 \\
\hline
\end{tabular}

${ }^{\mathrm{a}}$ Serial number corresponds to the respective lane number given in the gel electrophoresis diagram shown in figure $3 \mathrm{a}, \mathrm{b}$

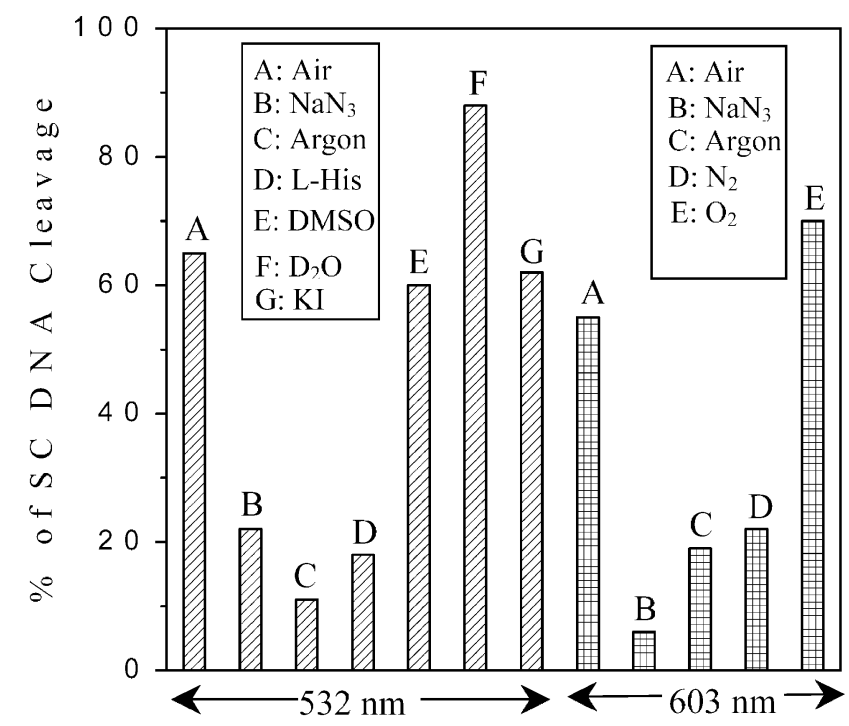

Figure 4. Bar diagram showing the percentage of SC pUC19 DNA cleavage by complex 9 at different reaction conditions upon irradiation with a mercury vapour lamp $(125 \mathrm{~W})$ of $532 \mathrm{~nm}$ for $10 \mathrm{~min}$ and $\mathrm{Nd}$ : YAG pulsed laser of $603 \mathrm{~nm}$ for $15 \mathrm{~min}(40 \mathrm{~mJ} / \mathrm{P})$. Control experiments in absence of 9 show SC DNA cleavage of $5 \%$ at $532 \mathrm{~nm}$ and $8 \%$ at $603 \mathrm{~nm}$.

cleavage. Hydroxyl radical scavengers like DMSO or KI do not show any significant effect on the cleavage activity. The results are indicative of the presence of a type-II process in which the photoexcited complex activates molecular oxygen from its

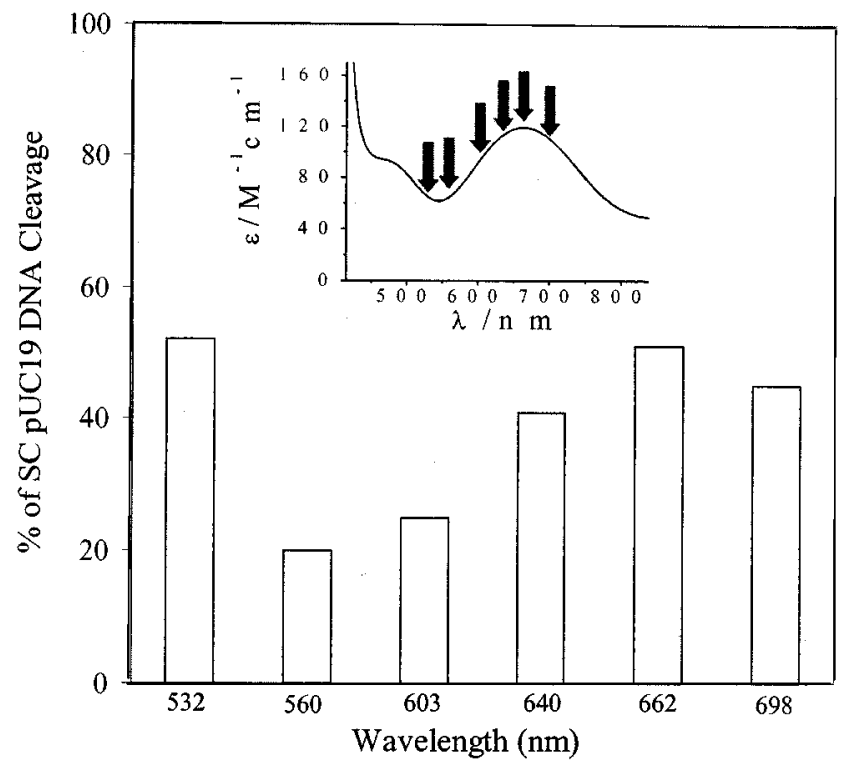

Figure 5. Photo-induced DNA cleavage activity of complex 9 at different wavelengths using Nd: YAG PDL system after 9000 laser shots at $20 \mathrm{~mJ} /$ pulse.

stable triplet to the cytotoxic singlet state. The cleavage pathway followed by these complexes is thus similar to those of the ternary amino acid copper(II) complexes containing phenanthroline bases.

The role of the copper(II) centre in 9 in the photoexcitation process has been examined by using wavelengths of $603,632 \cdot 8,640,662$, and $698 \mathrm{~nm}$ 
using a pulsed Nd:YAG laser dye laser system (Spectra Physics, $10 \mathrm{~Hz}, 5-7 \mathrm{~ns}, 20 \mathrm{~mJ} / \mathrm{P}$ power) under the $d-d$ transition band having a $\lambda_{\max }$ value of $661.5 \mathrm{~nm}$. In addition, wavelengths of 532 and $560 \mathrm{~nm}$ are chosen as they are near the strong LMCT (S-to-Cu) band with a peak at $390 \mathrm{~nm}$. The cleavage activity of $\mathbf{9}$ at the said wavelengths is shown in figure 5 and it follows the $d-d$ band giving highest percent of cleavage at $662 \mathrm{~nm}$. The results unequivocally show the involvement of the $d-d$ band in the photo-excitation process along with the LMCT band to generate excited species that subsequently form triplet species for activation of triplet oxygen to its cytotoxic singlet state. Variation of percentage DNA cleavage with laser power at different wavelengths using an Nd:YAG PDL system shows linear behaviour with similar slopes at different wavelengths. This suggests that the initial photoexcitation step is a single-photon process. DNA cleavage activity of the copper(II) complexes with a $\mathrm{Cu}^{\mathrm{II}} \mathrm{N}_{3} \mathrm{OS}$ core reveals that the sulphur atom bonded at the equatorial site has more photosensitizing effect than the one bonded at the elongated axial site.

\section{Dipyridoquinoxaline-copper(II) complex ${ }^{39}$}

It has been reported that DNA intercalator quinoxalines, similar to those present in antitumor antibiotics like echinomycin or triostin, cleave double-stranded DNA at $365 \mathrm{~nm}$ in the absence of any external reagents. ${ }^{40}$ The quinoxaline moiety with conjugated $\mathrm{C}=\mathrm{N}$ bond generates the photoexcited ${ }^{3}\left(n-\pi^{*}\right)$ and/or ${ }^{3}\left(\pi-\pi^{*}\right)$ state(s) which could cause DNA cleavage by $\mathrm{H}$-abstraction and/or electron transfer pathway(s). We have been interested in studying the effect on photo-induced DNA cleavage activity of metal binding to quinoxaline ligands. We have earlier reported the chemical nuclease activity of $\left[\mathrm{Cu}(\mathrm{dpq})_{2}\left(\mathrm{H}_{2} \mathrm{O}\right)\right]$ $\left(\mathrm{ClO}_{4}\right)_{2}$ (13) (scheme 3). ${ }^{41}$ This redox-active copper(II)

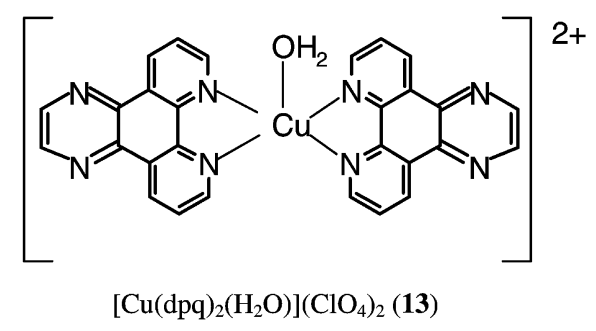

Scheme 3. Binary complex 13 having dipyridoquinoxaline moiety as photosensitizer. complex shows significantly enhanced chemical nuclease activity over its phen analogue and it is also active in efficiently cleaving SC DNA under hydrolytic reaction conditions with a rate of $5.58 \pm 0.4 \mathrm{~h}^{-1}$ and rate enhancement of $1.55 \times 10^{8}{ }^{42}$ Complex 13 is chosen for the photo-induced DNA cleavage study as its $d-d$ band at $673 \mathrm{~nm}$ in DMF-Tris buffer falls in the PDT window of $620-800 \mathrm{~nm}$ besides having efficient DNA binding dpq ligand with its quinoxaline moiety as photosensitizer.

Photo-induced DNA cleavage activity of the complex has been studied in Tris- $\mathrm{HCl} / \mathrm{NaCl}$ buffer of $\mathrm{pH}$ $7 \cdot 2$ at the wavelengths of $312 \mathrm{~nm}$ (UV lamp, $96 \mathrm{~W}$ ) and $694 \mathrm{~nm}$ (ruby laser, Lumonics make, $1 / 6 \mathrm{~Hz}$, $20 \mathrm{~ns}, 40 \mathrm{~mJ} \mathrm{P}^{-1}$ in single shot mode). Mechanistic studies have been done using a $\mathrm{CW} \mathrm{He}-\mathrm{Ne}$ laser $(3 \mathrm{~mW})$ of $632.8 \mathrm{~nm}$. DNA cleavage activity is shown in figures 6 and 7 and the data are given in table 3. The complex shows efficient cleavage of SC DNA to its NC form on photoexposure at $312 \mathrm{~nm}$. The cleavage reaction proceeds through a type-II process involving singlet oxygen $\left({ }^{1} \mathrm{O}_{2}\right)$ as the reactive species as evidenced from the inhibition of cleavage using sodium azide and enhancement of cleavage in $\mathrm{D}_{2} \mathrm{O}$ solvent. The complex shows electronic bands at 262, 291 and $337 \mathrm{~nm}$ in the UV region in DMF-Tris buffer. Photo-excitation at $312 \mathrm{~nm}$ could involve these dpq-based bands and the LMCT band forming ${ }^{3}\left(n-\pi^{*}\right)$ and $/$ or $^{3}\left(\pi-\pi^{*}\right)$ state(s).

The complex shows complete cleavage of DNA at $694 \mathrm{~nm}$ from a ruby laser using a complex concentration of $50 \mu \mathrm{M}$ for an exposure time of $1 \mathrm{~h}$ under aerobic reaction conditions (figure 6). While the bisdpq copper(II) complex cleaves DNA on exposure to both UV and red light, its bis-phen analogue is essentially inactive at these wavelengths. This is because of the photosensitizing ability of the dpq ligand having a quinoxaline moiety. Besides, dpq ligand is a better binder to DNA at the minor groove as compared to the phen ligand. Control experiments show that the dpq ligand alone is moderately cleav-

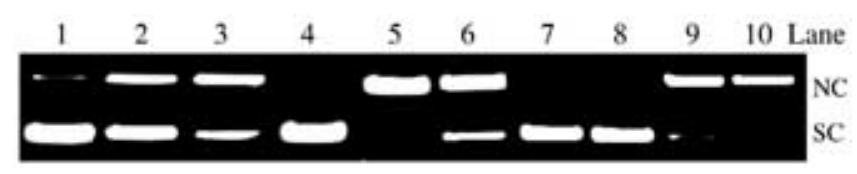

Figure 6. SC DNA $(0.5 \mu \mathrm{g})$ cleavage activity of complex 13 and dpq using UV light of $312 \mathrm{~nm}$ (lanes 1-6) and pulsed ruby laser $(694 \mathrm{~nm}, 40 \mathrm{~mJ} / \mathrm{P}$ peak power, lanes 7-10) with details of the reaction conditions given in table 3 . 
Table 3. Selected SC DNA cleavage data ${ }^{\mathrm{a}}$ of $\mathbf{1 3}$ and the dpq ligand.

\begin{tabular}{|c|c|c|c|c|c|}
\hline S. no. & Reaction condition & Complex $(\mu \mathrm{M})$ & $\lambda, \operatorname{nm}(t, \min )$ & $\mathrm{SC}(\%)$ & $\mathrm{NC}(\%)$ \\
\hline \multicolumn{6}{|c|}{ Light source: $U V$ light $(96 \mathrm{~W})$ (data for figure 6) } \\
\hline 1. & DNA control & - & 312 [10] & 91 & 9 \\
\hline 2. & $\mathrm{DNA}+\mathrm{dpq}$ & 50 & $312[10]$ & 57 & 43 \\
\hline 3. & $\mathrm{DNA}+\mathbf{1 3}$ & 25 & $312[10]$ & 39 & 61 \\
\hline 4. & $\mathrm{DNA}+\mathrm{NaN}_{3}(150 \mu \mathrm{M})+\mathbf{1 3}$ & 25 & $312[10]$ & 93 & 7 \\
\hline 5. & $\mathrm{DNA}+\mathrm{D}_{2} \mathrm{O}(14 \mu \mathrm{l})+\mathbf{1 3}$ & 25 & $312[10]$ & 1 & 99 \\
\hline 6. & DNA + DMSO $(2 \mu \mathrm{l})+\mathbf{1 3}$ & 25 & $312[10]$ & 41 & 59 \\
\hline \multicolumn{6}{|c|}{ Light source: pulsed ruby laser (data for figure 6) } \\
\hline 7. & DNA control & - & $694[120]$ & 98 & 2 \\
\hline 8. & $\mathrm{DNA}+\mathrm{dpq}$ & 200 & $694[120]$ & 97 & 3 \\
\hline 9. & $\mathrm{DNA}+13$ & 25 & $694[120]$ & 6 & 94 \\
\hline 10. & $\mathrm{DNA}+\mathbf{1 3}$ & 100 & $694[30]$ & 1 & 99 \\
\hline
\end{tabular}

${ }^{\mathrm{a}}$ Serial number corresponds to the respective lane number given in gel electrophoresis diagram shown in figure 6

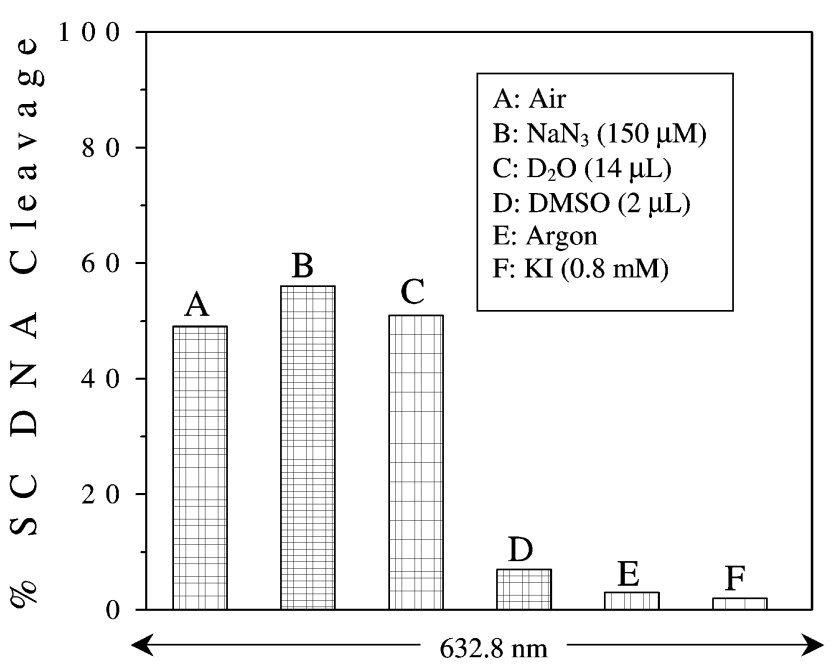

Figure 7. Cleavage of SC DNA $(0.5 \mu \mathrm{g})$ by $\mathbf{1 3}(80 \mu \mathrm{M})$ in the presence of different reagents using $\mathrm{CW}$ laser of $632.8 \mathrm{~nm}(3 \mathrm{~mW})$ for $30 \mathrm{~min}$ exposure time in $50 \mathrm{mM}$ Tris- $\mathrm{HCl} / \mathrm{NaCl}$ buffer (pH, 7.2) containing DMF (10\%).

age-active at $312 \mathrm{~nm}$ but does not show any apparent cleavage activity at red light. Observation of efficient nuclease activity at $694 \mathrm{~nm}$ thus indicates the involvement of the $d-d$ band $\left(\lambda_{\max }\right.$ at $673 \mathrm{~nm}$ ) of the complex in the cleavage reaction.

Mechanistic aspects of the red light-induced DNA cleavage reaction have been studied at $632.8 \mathrm{~nm}$ using a CW He-Ne laser $(3 \mathrm{~mW})$ and the relevant data are given in figure 7 . The complex is cleavage inactive under argon or nitrogen atmosphere indicating the necessity of oxygen in the cleavage reaction. Control experiments using singlet oxygen quencher sodium azide do not show any significant effect on the cleavage activity. Similarly, there is no apparent effect of $\mathrm{D}_{2} \mathrm{O}$ adition on the percentage of DNA cleavage. The cleavage data suggest the non-involvement of singlet oxygen in a type-II pathway. An alternate possibility is the involvement of hydroxyl radicals following a photo-redox pathway. Control experiments using hydroxyl radical scavengers like DMSO or mannitol show complete inhibition of the photo-cleavage activity of the complex on red-light irradiation. The results are indicative of the involvement of hydroxyl radicals in the cleavage reaction. Formation of hydroxyl radicals on photo-irradiation of sulphur and selenium analogs of psoralen at $365 \mathrm{~nm}$ has earlier been reported by Collet et al. ${ }^{43}$ They have proposed an initial formation of a superoxide anion $\left(\mathrm{O}_{2}^{--}\right)$that converts to the hydroxyl radical.

The other possibility of formation of hydroxyl radical is from hydrogen peroxide formed in a way similar to that proposed for the chemical nuclease activity of the bis-phen copper species involving the $\mathrm{Cu}(\mathrm{II}) / \mathrm{Cu}(\mathrm{I})$ redox couple. ${ }^{44}$ The dpq complex shows quasi-reversible cyclic voltammetric response for the $\mathrm{Cu}(\mathrm{II}) / \mathrm{Cu}(\mathrm{I})$ couple giving the $E_{1 / 2}$ value of $0 \cdot 09 \mathrm{~V}$ vs SCE in DMF-Tris buffer/0.1M KCl. The photo-excitation at red light could lead to the reduction of copper(II) to its cuprous form by an electron transfer in the excited state. The copper(I) complex under aerobic reaction medium possibly activates oxygen to form hydrogen peroxide as a source of the hydroxyl radicals. Control experiments using KI as hydrogen peroxide scavenger show complete inhibition of DNA cleavage. This work exemplifies a metal-promoted efficient DNA cleavage activity of a 
Table 4. Photo-induced SC pUC19 DNA $(0 \cdot 5 \mu \mathrm{g})$ cleavage activity of complex $\mathbf{1 4}$ on exposure to UV and visible light of different wavelengths.

\begin{tabular}{|c|c|c|c|c|c|}
\hline S. no. & Reaction condition & Complex $(\mu \mathrm{M})$ & $\lambda, \mathrm{nm}(t, \min )$ & $\mathrm{SC}(\%)$ & $\mathrm{NC}(\%)$ \\
\hline \multicolumn{6}{|c|}{ Light source: $U V$ light $(96 W)$ (data for figure $8 \mathrm{a}$ ) } \\
\hline 1. & DNA control & - & $312[20]$ & 95 & 5 \\
\hline 2. & DNA $+\mathrm{H}_{2}$ RSSR $(400 \mu \mathrm{M})$ & & $312[20]$ & 97 & 3 \\
\hline 3. & $\mathrm{DNA}+\mathbf{1 4}$ & 200 & $312[5]$ & 18 & 82 \\
\hline 4. & $\mathrm{DNA}+\mathrm{NaN}_{3}(200 \mu \mathrm{M})+\mathbf{1 4}$ & 200 & $312[5]$ & 83 & 17 \\
\hline 5. & $\mathrm{DNA}+\mathrm{D}_{2} \mathrm{O}(14 \mu)+\mathbf{1 4}$ & 100 & $312[10]$ & 1 & 99 \\
\hline 6. & $\mathrm{DNA}+\mathrm{DMSO}(4 \mu \mathrm{l})+\mathbf{1 4}$ & 200 & $312[10]$ & 17 & 83 \\
\hline 7. & DNA + 14 (under argon) & 200 & $312[10]$ & 94 & 6 \\
\hline \multicolumn{6}{|c|}{ Light source: $C W$ laser $(3 \mathrm{~mW})$ (data for figure $8 \mathrm{~b}$ ) } \\
\hline 1. & DNA control & - & $632 \cdot 8[180]$ & 97 & 3 \\
\hline 2. & $\mathrm{DNA}+\mathbf{1 4}$ & 300 & $632 \cdot 8[180]$ & 51 & 49 \\
\hline 3. & $\mathrm{DNA}+\mathrm{NaN}_{3}(300 \mu \mathrm{M})+\mathbf{1 4}$ & 300 & $632 \cdot 8[180]$ & 56 & 44 \\
\hline 4. & $\mathrm{DNA}+\mathrm{DMSO}(4 \mu \mathrm{L})+\mathbf{1 4}$ & 300 & $632 \cdot 8[180]$ & 98 & 2 \\
\hline 5. & DNA + 14 (under argon) & 300 & $632 \cdot 8[180]$ & 75 & 25 \\
\hline \multicolumn{6}{|c|}{ Light source: pulsed ruby laser (data for figure $8 \mathrm{~b}$ ) } \\
\hline 6. & DNA control & - & $694[240]$ & 97 & 3 \\
\hline 7. & $\mathrm{DNA}+\mathbf{1 4}$ & 300 & $694[180]$ & 40 & 60 \\
\hline 8. & $\mathrm{DNA}+14$ & 400 & $694[240]$ & 2 & 98 \\
\hline
\end{tabular}

${ }^{\mathrm{a}}$ Serial number corresponds to the respective lane number given in the gel electrophoresis diagram shown in figure $8 \mathrm{a}, \mathrm{b}$

quinoxaline-copper(II) complex at $\sim 700 \mathrm{~nm}$. The DNA cleavage pathway on red-light exposure involves hydroxyl radicals for this bis-dpq copper(II) complex. In contrast, the mechanistic pathway observed for ternary amino acid-copper(II) complexes with phenanthroline bases and copper(II) complexes with the metal bound to thiomethyl groups in $\mathrm{CuN}_{3} \mathrm{OS}$ cores involve singlet oxygen as the cleavage active species in a type-II pathway.

\section{Binuclear copper(II) complex having a disulphide moiety $^{45}$}

It is known that thio-containing natural product antibiotics and their analogues show DNA cleavage activity. ${ }^{46-50}$ In general, the DNA cleavage activity of such sulphur compounds follows thiol-dependent pathways that are of Fenton-type, involving activation of molecular oxygen to form hydrogen peroxide in a metal-mediated process resulting in generation of cytotoxic hydroxyl radicals as DNA cleaving agent. We have observed that redox active copper(II) complexes with a $\mathrm{CuN}_{3} \mathrm{SO}$ core are efficient cleavers of DNA in an oxidative process either using a reducing agent like mercaptopropionic acid or on light exposure under aerobic reaction conditions. ${ }^{36,37}$ Photo-excitation of the sulphur-to-copper charge transfer band along with the $d-d$ band excitation yields singlet oxygen as the cytotoxic agent. We have also observed that ternary amino acid complex $[\mathrm{Cu}(\mathrm{L}-\mathrm{met})($ phen $)(\mathrm{MeOH})]\left(\mathrm{ClO}_{4}\right)$ containing a pendant thiomethyl group of L-methionine is less efficient in showing DNA cleavage activity in comparison to the ternary species having a $\mathrm{Cu}-\mathrm{S}$ bond. ${ }^{24,37} \mathrm{It}$ is thus of interest to see the effect of ligands having a metal non-bound disulphide (-S-S-) moiety on the overall photo-induced DNA cleavage activity. Formation and cleavage of disulphide bonds are known to be responsible for the biological activity of several sulphur-containing peptides and proteins. ${ }^{51-53} \mathrm{We}$ have prepared a dicopper(II) complex $\left[\mathrm{Cu}_{2}(\mathrm{RSSR})_{2}\right](\mathbf{1 4})$ containing a dianionic tetradentate Schiff base having an exterior disulfide moiety (scheme 4).

Complex 14 shows DNA cleavage activity on irradiation with UV light of $312 \mathrm{~nm}$ or red light of $632 \cdot 8 \mathrm{~nm}$ and $694 \mathrm{~nm}$ (table 4, figure 8). The complex at $312 \mathrm{~nm}$ photoexposure is cleavage-active only under aerobic conditions suggesting the necessity of oxygen for the DNA cleavage. Addition of sodium azide or histidine inhibits the cleavage, addition of $\mathrm{D}_{2} \mathrm{O}$ significantly augments the cleavage activity, and there is no apparent effect of DMSO addition to the cleavage activity. Data from control experiments indicate the involvement of singlet oxygen in a type- 
II pathway. The disulphide moiety plays an important role as control experiments with a bis-ligand copper(II) complex with a Schiff base 2-(phenylthio)ethylsalicylaldimine with $\mathrm{CuN}_{2} \mathrm{O}_{2}$ coordination, each ligand with a pendant $-\mathrm{SPh}$ moiety, does not show any apparent DNA cleavage at this wavelength. The Schiff base ligand $\mathrm{H}_{2} \mathrm{RSSR}$ alone is cleavage inactive. The results indicate the importance of both

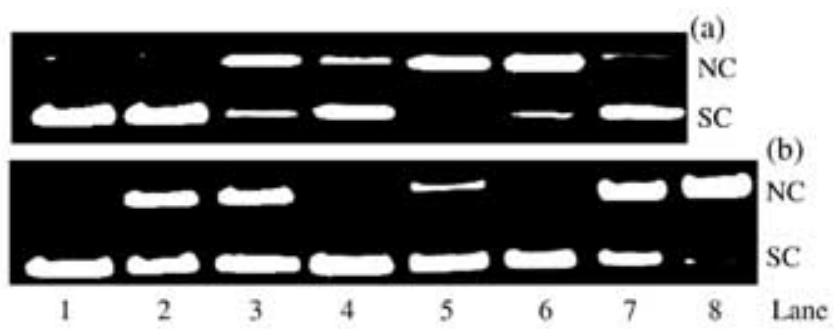

Figure 8. (a) Gel electrophoresis diagram showing the cleavage of SC pUC19 DNA $(0.5 \mu \mathrm{g})$ by 14 on UV light $(312 \mathrm{~nm})$ irradiation followed by incubation $(1 \mathrm{~h})$ under dark in $50 \mathrm{mM}$ Tris- $\mathrm{HCl} / \mathrm{NaCl}$ buffer $(\mathrm{pH}, 7 \cdot 2)$ containing DMF $(10 \%)$. The reactions were carried out under aerobic conditions except for lane no. 7 for which the reaction was done under argon. (b) Red light-induced cleavage of SC pUC19 DNA by $14(300 \mu \mathrm{M})$ in $50 \mathrm{mM}$ Tris- $\mathrm{HCl} / \mathrm{NaCl}$ buffer $(\mathrm{pH}, 7 \cdot 2)$ containing DMF $(10 \%)$ using $632.8 \mathrm{~nm} \mathrm{CW}$ laser (3 $\mathrm{mW}$ ) (lanes 1-5) at different exposure times and pulsed ruby laser $(694 \mathrm{~nm}, 40 \mathrm{~mJ} / \mathrm{P}$ peak power) (lanes 6-8) under aerobic condition except lane number 5. Details of the reaction conditions are given in table 4 .

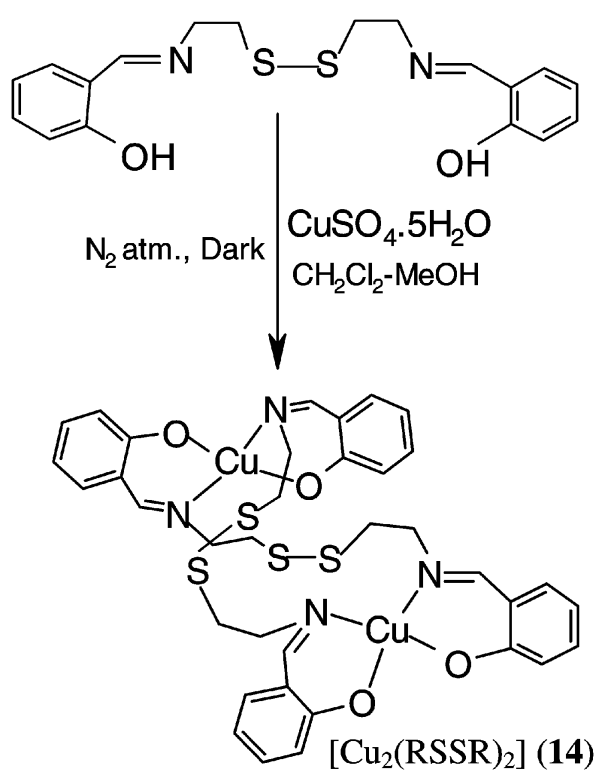

Scheme 4. Reaction pathway for the synthesis of $\left[\mathrm{Cu}_{2}(\mathrm{RSSR})_{2}\right](\mathbf{1 4})$.

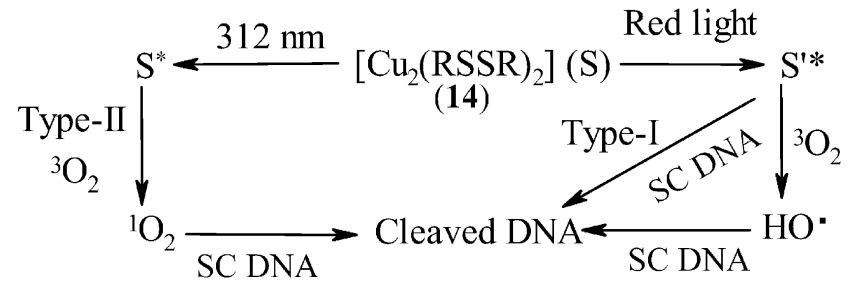

Scheme 5. Proposed mechanistic pathways involved for the photo-induced cleavage of SC-DNA by $\left[\mathrm{Cu}_{2}(\mathrm{RSSR})_{2}\right]$ (14).

the copper and the disulphide moiety in the complex for observing the photo-induced DNA cleavage activity. Photo-excitation at $312 \mathrm{~nm}$ is proposed to generate a triplet-excited state involving charge transfer bands near 300 and $309 \mathrm{~nm}$ in conjunction with the disulphide group to form singlet oxygen by energy transfer (scheme 5).

The complex exhibits significant cleavage of SC DNA to its NC form on exposure to red light of $632.8 \mathrm{~nm}$ (CW He-Ne laser) or $694 \mathrm{~nm}$ (ruby laser). Interestingly, the cleavage reaction at red light involves hydroxyl radical pathway as DMSO addition completely inhibits the cleavage and sodium azide addition shows no apparent effect. In addition, the complex shows appreciable DNA cleavage under anaerobic condition at $632.8 \mathrm{~nm}$. It is proposed that red light exposure leads to the formation of sulphide radicals that can cleave SC DNA in a type-I process or could generate reactive hydroxyl radicals on activation of molecular oxygen (scheme 5 ) ${ }^{54}$

\section{Conclusion}

Photo-induced DNA cleavage activity of the binary and ternary copper(II) complexes reveals the important roles of the paramagnetic transition metal, DNA binder phenanthroline bases and the photosensitizers. Red light-induced DNA cleavage activity of the present complexes is of significance as binding of transition metal like copper(II) to porphyrin bases leads to reduction in cleavage activity. Long wavelength DNA cleavage activity makes these copper(II) complexes potential candidates for further design of molecules suitable for PDT applications and as alternatives to the PDT anticancer drug, Photofrin ${ }^{\circledR}$.

The red-light DNA cleavage activity of the bisdpq copper(II) complex is of importance for designing analogous complexes with hybrid quinoxalines for cellular applications and towards understanding 
the function of quinoxaline-based antitumor antibiotics in the presence of bio-essential copper ions. The ternary amino acid-copper(II) complexes are also useful for designing peptide-based conjugates containing metal ion for cellular application. Sulphurcontaining ligands with their longer triplet state lifetimes are suitable for activation of molecular oxygen. DNA cleavage under anaerobic conditions has potential advantages in therapeutic applications.

DNA cleavage activity of the copper(II) complexes on red light exposure presents the first direct evidence for the dual involvement of the copper(II) $d-d$ band and the ligand-to-metal charge transfer band in the photosensitization process leading to an efficient DNA cleavage activity at wavelengths within the PDT window. This work has opened up a new area of research involving $3 d$-metal complexes for photocleavage of DNA with an objective for future PDT applications.

\section{Acknowledgements}

The author acknowledges the collaboration of his colleagues and students, specially Prof P K Das, Dr M Nethaji, Dr S Dhar, Dr D Senapati and Mr A K Patra. The author also thanks the Department of Science and Technology, Government of India, and the Council of Scientific and Industrial Research, New Delhi, for financial support.

\section{References}

1. Sigman D S, Mazumdar A and Perrin D M 1993 Chem. Rev. 932295

2. Erkkila K E, Odom D T and Barton J K 1999 Chem. Rev. 992777

3. Szacilowski K, Macyk W, Drzewiecka-Matuszek A, Brindell M and Stochel G 2005 Chem. Rev. 1052647

4. Lippard S J 1999 Chem. Rev. 992467

5. Reedijk J 2001 J. Inorg. Biochem. 8689

6. Burrows C J and Muller J G 1998 Chem. Rev. 98 1109

7. Armitage B 1998 Chem. Rev. 981171

8. McMillin D R and McNett K M 1998 Chem. Rev. 98 1201

9. Pogozelski W K and Tullius T D 1998 Chem. Rev. 98 1089

10. Pratviel G, Bernadou J and Meunier B $1998 A d v$. Inorg. Chem. 45251

11. Sigman D S, Graham D R, D'Aurora V and Stern A M 1979 J. Biol. Chem. 25412269

12. Umezawa H 1976 Prog. Biochem. Pharmacol. 1118
13. Burger R M 1998 Chem. Rev. 981153

14. Ali H and VanLier J E 1999 Chem. Rev. 992379

15. Sessler M C, Hemmi G, Mody T D, Murai T, Burrel A and Young S W 1994 Acc. Chem. Res. 2743

16. Sternberg E D, Dolphin D and Brückner C 1998 Tetrahedron 544151

17. Henderson B W, Busch T M, Vaughan L A, Frawley N P, Babich D, Sosa T A, Zollo J D, Dee A S, Cooper M T, Bellnier D A, Greco W R and Oseroff A R 2000 Cancer Res. 60525

18. Praseuth D, Gaudemer A, Verlhac J B, Kraljiě I, Sissoëff I and Guilé E 1986 Photochem. Photobiol. 44 717

19. Sommer S, Rimington C and Moan J 1984 FEBS Lett. 172267

20. Eppley H J, Lato S M, Ellington A D and Zalesky J M 1999 Chem. Commun. 2405

21. Benites P J, Holmberg R C, Rawat D S, Kraft B J, Klein L J, Peters D G, Thorp H H and Zaleski J M 2003 J. Am. Chem. Soc. 1256434

22. Maurer T D, Kraft B J, Lato S M, Ellington A D and Zaleski J M 2000 Chem. Commun. 69

23. Patra A K, Dhar S, Nethaji M and Chakravarty A R 2003 Chem. Commun. 1562

24. Patra A K, Dhar S, Nethaji M and Chakravarty A R 2005 Dalton Trans. 896

25. Patra A K, Nethaji M and Chakravarty A R 2005 Dalton Trans. 2798

26. Ren R, Yang P, Zheng W and Hua Z 2000 Inorg. Chem. 395454

27. Roger T K, Joel T W and Sonya J F 2003 J. Am. Chem. Soc. 1256656

28. Raso A G, Fiol J J, Adrover B, Moreno V, Mata I, Espinosa E and Molins E 2003 J. Inorg. Biochem. 95 77

29. John D C A 1993 Biochem. J. 289463

30. Cheng C-T, Lo V, Chen J, Chen W-C, Lin C-Y, Yang H-C and Sheh L 2001 Bioorg. Med. Chem. 91493

31. Mahon Jr K P, Ortiz-Meoz R F, Prestwich E G and Kelly S O 2003 Chem. Commun. 1956

32. Kovalenko S V and Alabugin I V 2005 Chem. Commun. 1444

33. Saito I and Takayama M 1995 J. Am. Chem. Soc. 117 5590

34. Herebian D and Sheldrick W S 2002 Dalton Trans. 966

35. Khan A U 1976 J. Phys. Chem. 802219

36. Dhar S and Chakravarty A R 2003 Inorg. Chem. 42 2483

37. Dhar S, Senapati D, Das P K, Chattopadhyay P, Nethaji M and Chakravarty A R 2003 J. Am. Chem. Soc. 12512118

38. Quian X, Huang T-B, Wei D-Z, Zhu D-H, Fan M-C and Yao W 2000 J. Chem. Soc., Perkin Trans. 2715

39. Dhar S, Senapati D, Reddy P A N, Das P K and Chakravarty A R 2003 Chem. Commun. 2452

40. Toshima K, Takano R, Ozawa T and Matsumura S 2002 Chem. Commun. 212 
41. Santra B K, Reddy P A N, Neelakanta G, Mahadevan S, Nethaji M and Chakravarty A R 2002 J. Inorg. Biochem. 89191

42. Dhar S, Reddy P A N and Chakravarty A R 2004 Dalton Trans. 697

43. Collet M, Hoebeke M, Pitte J, Jacobs A, Lindqvist L and Van de Vorst A 1996 J. Photochem. Photobiol. B35 221

44. Sigman D S, Bruice T W, Mazumder A and Sutton C L 1993 Acc. Chem. Res. 2698

45. Dhar S, Nethaji M and Chakravarty A R 2005 Dalton Trans. 344

46. Mitra K, Kim W, Daniels J S and Gates K S 1997 Biochemistry 11911691

47. Chatterjee M, Cramer K D and Townsend C A 1993 J. Am. Chem. Soc. 1153374
48. Asai A, Hara M, Kakita S, Kanda Y, Yoshida M, Saito H and Saitoh Y 1996 J. Am. Chem. Soc. 118 6802

49. Davidson B S, Molinski T F, Barrows L R and Ireland C M 1991 J. Am. Chem. Soc. 1134709

50. Behroozi S J, Kim W, Dannaldson J and Gates K S 1996 Biochemistry 351768

51. Saranak J and Foster K W 2000 Biochem. Biophys. Res. Commun. 275286

52. Gilbert B C, Silvester S, Walton P H and Whitwood A C 1999 J. Chem. Soc., Perkin Trans. 21891

53. Jacob C, Giles G L, Giles N M and Sies H 2003 Angew. Chem. Int. Ed. 424742

54. Tapley D W, Buettner G R and Shick J M 1999 Biol. Bull. 19652 